\title{
SUSTAINABILITY AND PERFORMANCE IN AGRIBUSINESSES: THE CASE OF VEGETABLE EXPORT BUSINESSES IN MEXICO
}

\author{
Carlos Armando, JACOBO-HERNANDEZ ${ }^{1}$, Melissa, BARRÓN-BORQUEZ ${ }^{2}$ and Sergio, OCHOA- \\ JIMÉNEZ \\ ${ }^{1}$ Instituto Tecnológico de Sonora, Mexico, carlos.jacobo@itson.edu.mx \\ ${ }^{2}$ Instituto Tecnológico de Sonora, Mexico, melissabarron@hotmail.com \\ ${ }^{3}$ Instituto Tecnológico de Sonora, Mexico, sergio.ochoa@itson.edu.mx
}

\begin{abstract}
The study of sustainability has become an increasingly relevant topic for governments, companies, and researchers. As a result, the number of studies in this field has increased substantially, with a special focus on agribusiness. This study aims to analyze the performance of vegetable export enterprises in Mexico, taking into account the economic, social, and environmental dimensions of sustainability. To achieve this objective, a survey was designed and administered to vegetable exporters in the northwest of Mexico, and indicators were created that allowed each of the dimensions of sustainability to be evaluated. Additionally, a semi-structured interview was designed and conducted in a specific export company. The results indicate that performance is strongly oriented towards economic goals and that the social and environmental aspects of sustainability are not prioritized. In conclusion, one can claim that there is an imbalance among the three dimensions of sustainability within the companies studied, with performance primarily focusing on financial and economic indicators.
\end{abstract}

KEY WORDS: Sustainability, Performance, Export businesses.

\section{INTRODUCTION}

Economists and ecologists take different approaches to the concept of sustainability within organizations. Dyllic and Hockerts (2002) divide sustainability into three distinct approaches: economic, social, and environmental. In this schema, the economic focus seeks to ensure liquidity for shareholders; the social focus seeks to increase value for the communities where companies operate by increasing human capital and fostering interest in the company's values; and finally, the environmental focus proposes that natural resources be used in moderation and with low levels of pollution.

A sustainable organization incorporates an environmental perspective into its values. According to Vargas-Hernández (2010), the goal of adopting a culture of responsible behavior during the production of goods and/or services is to strengthen eco-efficiency as an organizational culture with the goal of achieving the sound use of natural resources.

Within this context, the Mexican model of development is through trade opening. Mexico currently positions itself in the international realm through various international trade agreements, and its food and agriculture sector has allowed the country to expand its exports and imports. Between 1996 and 2006, imports increased $7.9 \%$ annually, whereas exports increased by $9.1 \%$, fostering greater economic growth and integration with foreign markets (Secretaria de agricultura, ganadería, desarrollo rural, pesca y alimentación - SAGARPA, 2007).
Mexico's advantages over other countries with regard to access to U.S. markets have allowed the United States to become Mexico's primary customer for food and agricultural exports. The establishment of the North American Free Trade Agreement (NAFTA) gave Mexico an additional trade advantage (Málaga and Williams, 2010)

\section{LITERATURE REVIEW}

\section{Sustainable development}

The concept of sustainability was officially established in the 1987 Brundtland report, which established that "sustainable development is development that meets the needs of the present without compromising the ability of future generations to meet their own needs" (Naciones Unidas, 1987).

According to Velázquez and Bohórquez (2014), the concept of sustainability proposed by the Brundtland report relates to changes in society's social environment and ethical principles, among them responsibility, respect for one's surroundings, nature, and peaceful coexistence between members of society.

Human development is central to the concept of sustainability. Social and cultural capital, ethics, and freedom are fundamental components in measuring sustainability, given that poverty, the economic needs of a community, and the lack of job opportunities are the main obstacles to human beings' ability to holistically develop (Caldera, Ortega, and Escamilla, 2012).

For Doane and MacGillivray (2001), economic sustainability is linked to the organization's social and environmental outcomes, 
and sustainable development is defined as a dynamic process that supports people to increase their potential by improving their quality of life and protecting and improving the environment in which they live.

\section{Approaches to sustainability}

The concept of sustainability has a global focus that centers on the responsible and fair use of environmental and material resources. As such, it is traditionally approached through three dimensions: environmental, social, and economic (Cruz and Adam, 2014).

Environmental. This dimension refers to the environment in which human beings live, that is, the space that surrounds them and from which they obtain the resources necessary for their survival. These resources include water, food, fuel, and raw material to create the products that they use on a daily basis.

Social. This dimension refers to the fact that a community must be governed by premises that allow it to care for the space in which it exists, characterized by the reasonable consumption of the products that are necessary for it to subsist.

Economic. This dimension studies human beings' needs against nature's limited or scarce resources. Within the sustainability framework, it refers human beings' achievement of harmony between basic needs and satisfaction.

For Constanza, Alperovitz, Daly, Farley, Franco, Jackson, Kubiszewski, Schor, and Víctor (2012), sustainability from the environmental perspective involves adjusting to the fact that social capital and natural capital are not endlessly renewable. Human capital is the real biophysical limit, and the planet's capacity limits the expansion of economic markets.

\section{Economic and organizational performance}

In recent years, perspectives in business have changed because organizations cannot exclusively focus on obtaining financial resources. Investors must also consider other factors involved in sustainable development.

In addition to industrial development, the constant growth of the population and thus of cities leads to a series of processes in the environment that transform and/or destroy ecological equilibrium; for Rubio (1999), industrialization is the most significant factor impacting the environment, given that pollution of the atmosphere, waste dumped in rivers and the sea, etc., should to be analyzed to find alternatives that minimize negative environmental impacts.

As the environment becomes an increasingly important topic, businesses should take a range of actions to establish environmental guidelines, developing preventative or corrective actions that put them on a path towards eco-efficiency. That is, they should do more with less, scale down expenses, and reduce, reuse, and recycle (Rubio, 1999).

The proposals noted above have given rise to the so-called Environmental Management System, a method that an organization may follow to achieve the defined goals for its behavior, heeding regulations, environmental risks, and social, financial, and economic pressures (Rubio, 1999).

Within the current economic context, small and medium-sized enterprises (SMEs) have been studied for their contributions to a country's economy in areas such as job creation; Mendoza and Hernández (2008) affirm that SMEs are units of business that represent a key sector within the economy, given that they have more formal organizational structures.
Within an organization, partners and executives prioritize that the organization's profits and performance results be superior to those of competitors, given that increased profitability indicates the degree of progress achieved by an organization with respect to its stated goals. Improvements in organizational performance are reflected in monetary benefits and in a learning-oriented workplace culture (Cruz, Rojas, and Burgos, 2014).

Another perception of organizations is that they are webs of stakeholder relationships that compete for importance and power. As such, when competitiveness is used to evaluate and orient organizational performance, it must include controls on various organizational levels that can counter the demands of the competitive environment (Cruz et al., 2014).

\section{Economic sustainability and sustainable development in Mexican small, medium, and micro-enterprises}

The growing use of natural resources and the degradation of systems have caused diverse international organizations to focus on addressing this issue. As a result, according to Álvarez, Castro, and Landazury (2014), the importance of sustainable development has emerged in response to the deterioration being experienced by global systems of life. This deterioration could lead to biophysical impossibilities in the not-too-distant future.

Given that Mexico is a country primarily dedicated to production and marketing in the primary sector, it is necessary to consider the concept of sustainability from the perspective of farming. Espinosa, Wiggins, González, and Aguilar (2004) define agricultural sustainability as the successful manipulation of resources in farming to satisfy human needs while maintaining or improving human surroundings and achieving efficiency and equity.

In the final decade of the twentieth century, Mexico experienced changes resulting from its economic growth in the global sphere, which primarily resulted from its opening to trade. Its accelerated insertion into the global market has led to an interest in the impacts of environmental management and operations, given that the extensive exploitation of natural resources and minerals in the earth has led to an accelerating decline in the quality of the environment (Leal, González, and Herrera, 2013).

\section{PROBLEM STATEMENT}

Labor in Mexico's agricultural sector has traditionally been characterized by family businesses that use obsolete technologies to produce and transform raw materials. This phenomenon has been the starting point for various studies because, historically, these types of businesses exploited the resources they needed to successfully perform their activities and they had no traditions regarding the appropriate use of these resources.

Existing studies have focused on the topic of social and environmental sustainability and analyzed how the operations of a business complement one another to determine whether there exists a balance between business operations and sustainability. These studies propose that this balance and corporate social responsibility should be combined to create added value. They focus on SMEs, analyzing and evaluating an enterprise's information systems to find gaps between the desired standards for a sustainability information system and the data they possess for the company under study. This is the case with the studies conducted by Molina, Sánchez, and Soto (2014), Akkerman, Farahani, and Grunow (2010), and Caldelli and Parmigiani (2004). 
Although diverse preexisting studies address the topics of sustainability and performance in family businesses or traditional business units, a lack of studies on vegetableexporting enterprises and their relationship with these topics has been detected. Thus, it is imperative to conduct this study to eliminate this information gap.

Given this context, this study aims to contribute valuable information. To that end, it is necessary to ask the following: How do vegetable exporters perform, taking into account the economic, social, and environmental factors that comprise sustainability?

\section{OBJECTIVE}

This study's primary objective is to analyze the performance of vegetable exporters, taking into account economic, social, and environmental factors to offer a panorama of the sector's current situation.

\section{METHODOLOGY}

This is a mixed methods descriptive study that considers a number of agribusinesses. A survey was administered to the businesses to gather the necessary information, and qualitative elements were addressed in a case study on one vegetable exporter. Doing so allowed for a behavioral analysis using performance indicators for the three dimensions of sustainability.

The subjects selected for the study were the horticultural enterprises of the Yaqui Valley in the state of Sonora, Mexico. There are a total of 25 companies that export products including squash, broccoli, lettuce, potato, tomato, and bell pepper. These companies belong to the Association of Horticultural Producers of Yaqui and Mayo (Asociación de productores de hortalizas del Yaqui y Mayo - APHYM). The primary criteria for participation in this study were that the company's main activity be the production and foreign marketing of horticultural products.

Additionally, the "Productores del Rio Yaqui" company was selected as a case study. The company was chosen for this analysis because it could be considered to be representative of the remaining enterprises in the region, given its track record in the production and exportation of vegetables.

The study population was the 25 companies belonging to the Association of Horticultural Producers of Yaqui and Mayo that market their products abroad and that agreed to participate in the study.
Two fundamental instruments were designed to collect information for this study. The first instrument is a questionnaire directed at businessmen to gather information that could be analyzed using to the dimensions of sustainable business performance. The instrument was designed with Krajnc and Glavic (2003) in mind, and it is divided into four sections: the first focuses on general characteristics, including the primary crop marketed by the company, the destination market, the average sale price, and the number of employees. The following three sections focus on the sustainability indicators (social, economic, and environmental factors), developed with questions that allow for comparisons between the various surveyed businesses.

The second instrument is a semi-structured interview guide directed at a specific company that produces and exports vegetables; this interview guide is divided into four sections. The first section includes the general characteristics of the company, including its name, destination market, and cultivated area; the second section addresses social factors and includes topics such as the number of jobs created per agricultural cycle, the factors that are taken into account during the hiring process for these jobs, and the role that the company ought to play in the development of the community where it operates. The third section includes economic topics such as production during the agricultural cycle and the benefits of selling abroad versus selling to the domestic market. The fourth and final section brings in the environmental factor, with questions about the use of resources such as water and energy, in addition to residue and waste management.

\section{RESULTS}

The following section displays the results of an analysis of the collected data. From these results, the necessary information can be obtained to analyze the sustainability levels for companies in southern Sonora.

\section{Vegetable exporters}

Within each dimension of sustainable business (social, economic, and environmental), various indicators were developed. Each was analyzed using formulas (ratios) that allowed the resulting information to be comparable and measurable across the companies that agreed to participate in the study. The results obtained are as follows:

Table 1 . Mean results by indicator

\begin{tabular}{|c|c|c|c|}
\hline & INDICATOR & MEAN & RANGE \\
\hline \multirow{5}{*}{ SOCIAL } & Employees with social security & 0.45 & 0 to 1 \\
\cline { 2 - 4 } & Differently abled employees & 0.01 & 0 to 1 \\
\cline { 2 - 4 } & Job creation & 0.59 & 0 to 1 \\
\cline { 2 - 4 } & Employees per hectare & 4.72 & 0 to 1 \\
\cline { 2 - 4 } & Support for community events & 0.001 & 0 to 1 \\
\hline \multirow{5}{*}{ ECONOMIC } & Gross income per hectare & $\$ 571,288.16$ & - \\
\cline { 2 - 4 } & Profit margin & 0.42 & - \\
\hline \multirow{5}{*}{ ENVIRONMENTAL } & Organic fertilizer usage rate (ltr) & 305 & - \\
\cline { 2 - 4 } & Agrochemical usage rate (ltr) & 1,092 & - \\
\cline { 2 - 4 } & Efficiency in use of water (m3) & 8,981 & - \\
\cline { 2 - 4 } & Efficiency in use of energy $(\mathrm{kw})$ & 1,121 & - \\
\hline
\end{tabular}




\section{Social dimension}

Five indicators were developed to illustrate a clear picture of the sector with regard to the social dimension. The first indicator, designated "employees with social security," emerged under the premise of determining the ratio of employees who work for the company and consistently have access to services via social security. The average was 0.45 , with zero indicating the least favorable ratio and one the most favorable. This indicator shows that in this area, companies in the region are moderately sustainable with regard to social security and/or basic medical services for their employees.

It should be noted that some of the companies surveyed explained that they only provide regular social security to employees with greater seniority and a higher degree of "trust," whereas for the remaining employees, the company pays a general fee for insurance to a medical center. An employee who needs medical care then receives a medical pass for a consultation and for medication, when necessary.

An alternative to increasing the average for this indicator is to offer $100 \%$ of regular employee social security, given that it is one of the benefits inherent to any employer-employee contract when an employment relationship is established. As such, in failing to provide this type of benefit to an employee, the company is committing a labor violation that could harm its business.

The indicator designated "differently abled employees" was included under the premise of measuring empathy among the businesses in the region with regard to hiring people with some type of physical or mental disability who can complete the tasks required by the company in a satisfactory manner. The indicator was calculated using a range of zero to one, in which zero was the lowest value and one was the highest possible value. The result of 0.01 reveals that the surveyed companies are not sustainable in the slightest with respect to this indicator.

Among the surveyed companies, only $20 \%$ hire this type of person. Although it is worth highlighting that to be successfully performed, certain production processes within the daily operations of this type of company require labor that is skilled to some degree, there are certain activities that differently abled people can efficiently complete.

To raise this indicator, it is important that the sector break with paradigms and stereotypes that are deeply held in contemporary society, that is, starting to offer employment opportunities to people who are physically and/or mentally different from the rest by focusing on individuals' work performance.

The third indicator developed for the social dimension, designated "job creation," aims to calculate the average rate of hiring from the community where the company is based, that is, how much of the labor force comes from the communities that surround the company. This indicator was calculated using a range of zero to one, with zero being the lowest value and one being the highest possible value. The result obtained from the surveys is 0.59 , which is above the mean needed to achieve social sustainability for this dimension.

This figure indicates that over $50 \%$ of the companies surveyed primarily hire people who live near company facilities. Employing local people stimulates economic activity in nearby areas or communities and, as a result, improves the life expectancy of and quality of life for local residents. Hiring locally also lowers costs for businesses, owing to lower absenteeism and lower employee transportation costs.
The indicator "employees per hectare" sought to calculate the mean number of employees required per hectare of crop planted by the company. The results from the surveyed companies reveal an average of 4.72 jobs per hectare of crop. It is worth highlighting that the number of employees depends on the type of crop for each harvest and on the process required to produce and market the crop.

The final indicator developed for the social dimension, designated "support for community events," seeks to show a broad panorama of the support that the company offers the community in which it is established, whether through sponsorships and/or donations to educational institutions or cultural events and sports that promote the holistic development of individuals.

The measurement range for this indicator is from zero to one, with zero being the lowest value and one being the highest and/or most positive value. The result of 0.001 shows that these companies are not providing this type of community support. As a result, this is an area of improvement that should receive attention.

In analyzing the results of the indicators for the social dimensions of sustainability, one can clearly observe that the holistic development of the employee is not a priority, given that only the minimum employment benefits are offered, social security being the most important benefit for an employee and his family. Similarly, the indicators point to the hiring of differently abled people and support for community events as the areas in which improvement is most critical.

\section{Economic dimension}

Two indicators were developed with respect to the economic dimension of sustainability. They reveal the economic landscape of the horticultural companies under study.

The first indicator is designated "gross income per hectare" and aims to reveal how much money is generated each season per hectare planted. This figure is obtained via an analysis of the mean sale price for the product in the destination market abroad, in addition to the output per hectare of the relevant product.

The mean result obtained from the surveyed companies was $\$ 571,288.16$ pesos per hectare planted and sold, without subtracting production and marketing costs for the product. It should be noted that output per hectare can vary depending on diverse factors including the quality of the soil and of the inputs used, in addition to the type of vegetable being produced.

The second indicator developed is designated "profit margin" and aims to show the profits after the product is sold abroad, after subtracting the costs of production and marketing incurred over the course of the season.

The range of measurement for this indicator is from zero to one, with zero being the lowest value and one being the highest. The result was 0.42 , which indicates a profit of nearly $50 \%$ of the final sale price for the product; that is, after subtracting the production and marketing costs from the earnings from total sales, approximately $50 \%$ remains as profit for the company. As a result, this indicator is considered moderately sustainable.

In analyzing the results of the indicators that comprise the economic dimension of sustainability, one can observe that income per hectare is substantial even after taking investments into account. Similarly, the profit margin of almost $50 \%$ paints a picture of a somewhat profitable sector, giving companies 
income that could allow them to invest towards the social dimension of sustainability.

\section{Environmental dimension}

Four indicators were developed with regard to the environmental dimension of sustainability. They reveal the mean use of resources per hectare of land. The first two indicators, designated "organic and agrochemical fertilizer usage rates," aim to show the average use of these products, and they reveal that a mean of 350 liters of organic fertilizer and 1,092 liters of traditional agrochemicals are used per hectare. These figures illustrate the increasing tendency to use organic products and fertilizers to nourish plants, giving the product added value at the time of sale.

With regard to the "efficiency in use of water and energy" indicators, the results reveal that a mean of 8,981 cubic meters of water and 1,121 kilowatts of energy are used per hectare. These results indicate that efficiency in the use of water is an important area for improvement. Companies must pay a fee to Mexico's National Water Commission (CONAGUA) to use this resource, and practices such as drip irrigation should be implemented to save water. Such practices require a certain amount of investment in the necessary machinery, but in the medium term, the company will benefit because of the reduction in the cost of this natural resource.

By analyzing the indicators for the environmental dimension of sustainability, one can observe that natural resources such as water are being used in excess because traditional irrigation systems contribute to the waste of resources. It is essential for companies to adopt new technologies that help save resources, including the electrical power associated with the infrastructures used in produce-packing areas.

Finally, it is important to note that the use of organic fertilizers instead of traditional agrochemicals has grown within agribusinesses because, as has been noted throughout the study, the market is tending towards $100 \%$ organic products.

\section{CASE STUDY: THE 'PRODUCTORES DEL RÍO YAQUI” COMPANY}

During the study, an in-depth interview was conducted with one company in the region to analyze the current situation of the horticultural sector in the Yaqui Valley from a qualitative perspective.

The grower who was interviewed has approximately 30 years of experience growing and selling vegetables in domestic and international markets, with the latter being more profitable and therefore of greater importance. During the 2014-2015 agricultural cycle, this grower worked 10 hectares of his own arable land. Spaghetti squash was the grower's primary product.

The grower needs approximately 20 employees in the field per hectare and generated approximately 200 temporary jobs during the 2014-2015 cycle. The company hires from communities near the farm. Only the tractor driver received social security services and housing assistance. Some employees asked the grower to be enrolled in these types of services, given that the workers themselves pay fees to be able to enjoy these benefits.

The sale price for the grower's product abroad is determined by supply and demand, and during the 2014-2015 cycle, the sale price for spaghetti squash oscillated at approximately 18 dollars per 16-kilo box. The grower expressed that the season had brought a very good price, given that approximately 1,000 kilos were produced per hectare. In the case of this grower, there exists a commercial relationship with a distribution company located in Rio Rico, Arizona, in the United States, making it the grower's target market. The distribution company facilitates the process of meeting destination country requirements so that the export process can occur without complications.

It is important to note that external factors can affect production and output.

In growing vegetables, the company uses a drip irrigation system that allows it to optimize its use of water because it must pay a fee to CONAGUA to use this service. Moreover, the area where cultivation is performed does not have conventional electrical power, only a generator that uses diesel as fuel.

This company works in open fields, allowing it to use certain agrochemicals, in contrast to other types of cultivation (shade mesh or greenhouse). Approximately $70 \%$ of the fertilizer used is agrochemical, and $30 \%$ is composed of granulated organic fertilizer produced in Mexico. It is important to note that according to environmental regulations, agrochemical containers should be recycled to avoid environmental damage. However, this grower does not take steps to reuse these containers. Instead, waste is incinerated without special precautions, a practice that clearly harms the environment.

This case clearly demonstrates the need for evolution in traditional agriculture towards new technologies and a change in growers" "know-how." In this globalized era, it is imperative to pay attention to factors that contribute to caring for the environment (environmental dimension) and attending to the needs of society (social dimension), not only to finances and profits (economic dimension).

\section{CONCLUSION}

This study was designed with the goal of analyzing Mexican vegetable exporters' performance, taking into account the social, economic, and environmental dimensions of sustainability. To that end, a survey was designed and administered to companies in this sector to gather information for the creation of indicators that reflect the companies' current situation. Additionally, a semi-structured interview was designed to analyze a specific company as a case study and to obtain qualitative information.

The results support the idea that there is an imbalance among the dimensions of sustainability because the indicators for the economic dimension saw better results than the indicators for the social and environmental dimensions. This imbalance directly relates to the decisions made by those in charge of export businesses. One can perceive a greater concern for economic and financial factors than for social and environmental factors.

In both the survey administered to export businesses and the semi-structured case study interview, the results clearly shows that social and environmental factors are not prioritized by businessmen in this sector.

With regard to the social dimension, it is important to note that despite the fact that there is legislation in Mexico to regulate employment benefits for workers, it is a common practice for workers in these companies to be denied basic benefits, especially healthcare benefits.

Future studies could be conducted to analyze the sustainability performance indicators in other sectors of the economy, which would allow for a comparative analysis between sectors. Additionally, using more sophisticated statistical tests could contribute new knowledge to the field of sustainability and business performance studies. 


\section{REFERENCES}

1. Accinelli E. \& de la Fuente J. (2013). Responsabilidad social compartida, actividades empresariales y desarrollo sustentable, modelo matemático de las decisiones en la empresa. Contaduría \& Administración, vol. 58, núm. 3, pp. 227-248. Universidad Autónoma de México. Mexico. Accessed January 25, 2015 on http://www.redalyc.org/articuloBasic.oa?id=39527853010

2. Akkerman R., Farahani P. \& Grunow M. (2010). Quality, safety and sustainability in food distribution: a review of quantitative operations management approaches and challenges. Springer-Verlag, Berlin.

3. Álvarez, M., Castro, M. \& Landazuri, Y. (2014). Factibilidad financiera y sustentabilidad: el caso de una empresa productora de fertilizantes orgánicos en el Valle del Yaqui. On Jacobo, C., Hernández, S., Ochoa, S., Casas, E. y Olivas, E. (Coord.). Sustentabilidad y gestión en las organizaciones perspectivas teóricas e implicaciones prácticas. (pp. 377-405). Mexico, D.F: Editorial Fontamara.

4. Caldelli A. \& Parmigiani M. (2004). Management information system - a tool for corporate sustainability. Jurnal od Bussines Ethics. Sringer-Verlag, Berlín.

5. Caldera, D., Ortega, M.A. \& Escamilla, Z. (2012). En busca del desarrollo humano sustentable. Organizaciones de la sociedad civil en acción. On Morales, E., Navarro, G.N. y Santa Ana, M.B. (Coord.), Sustentabilidad, responsabilidad social y organizaciones. Dimensiones, retos y discusiones. (pp. 88-90). Mexico. Ed. Hess

6. Constanza R., Alperovitz G., Daly H., Farley J., Franco C., Jackson T., Kubiszewski I., Schor J. \& Victor P. (2012). Building a Sustainable and desirable economy-in-societyin-nature. New York: United Nations Division for Sustainable Development. Accessed February 23, 2015 on https://sustainabledevelopment.un.org/content/documents/ Building a Sustainable and Desirable Economy-inSociety-in-Nature.pdf

7. Cruz, M.A. \& Adam J.A. (2014). Valuación de organizaciones con una perspectiva sustentable. En Ibarra, L.E., Casas, E.V., Olivas, E., Jacobo, C.A. \& Leyva, B.A. (Coord.). Sustentabilidad, empresa y agroindustria: reflexiones y aplicaciones. (pp. 147-149). Mexico. Ed. Umbral digital.

8. Cruz, J., Rojas, G. \& Burgos, F. (2014). Evaluación del impacto de la cultura organizacional en el desempeño del personal. Un estudio empírico en las empresas de la industria manufacturera que cotizan en la Bolsa Mexicana de Valores. Asamblea General de ALAFEC. Panamá. Accessed February 12, 2015 on http://www.alafec.unam.mx/docs/asambleas/xiv/ponencias /1.07.pdf

9. Doane D. \& MacGillivray A. (2001). Economic sustainability the business of staying in business. Accessed January 25, $2015 \quad$ on http://projectsigma.co.uk/RnDStreams/RD_economic_sust ain.pdf

10. Dyllick T. \& Hockerts K. (2002). Beyond the business case for corpate sustainability. Business Strategy and the Environment, vol. 11, núm. 2, p. 130, 2002. United States. Accessed January 25, 2015 on http://www.cfi.unisg.ch/ /media/internet/content/dateien/i nstituteundcenters/iwoe/forschung $\% 20 \mathrm{nh} /$ beyond $\% 20$ the $\%$ 20business\%20case.pdf

11. Espinosa J., Wiggings S., González A. \& Aguilar U. (2004). Sustentabilidad económica a nivel empresa: aplicación a unidades familiares de producción de leche en México.
Instituto Nacional de Investigaciones Forestales, Agrícolas y Pecuarias, vol. 42, num. 1, pp. 55-70, Mexico. Accessed January $19, \quad 2015 \quad$ on http://www.redalyc.org/pdf/613/61342105.pdf

12. Krajnc, D. \& Glavic, P. (2003). Indicators of sustainable production. Clean technologies and environmental policy, 5, 279-288.

13. Leal F., González R. \& Herrera L. (2013). Capacidad financiera como fuente para el Desarrollo Sustentable: Caso Empresas Mexicanas. International Review of Business Research Papers. Vol. 9, núm. 2. Accessed february 17, 2015 on 2015 de http://moodle2.unid.edu.mx/dts_cursos_mdl/pos/AN/CA/ AM/07/Capacidad.pdf

14. Málaga J. \& Williams G. (2010). Competitividad de México en la exportación de productos agrícolas. Revista Mexicana de Agronegocios, vol. XIV, num. 27, pp. 295-309, Sociedad Mexicana de Administración Agropecuaria A.C., Mexico. Accessed January 28, 2015 on http://www.redalyc.org/articulo.oa?id=14114743002

15. Mendoza J. \& Hernández M. (2008). Las prácticas de recursos humanos y su relación con el desempeño percibido de las pequeñas empresas. Revista Forum Empresarial. Vol. 13, num. 2. Pp. 23-43.

16. Molina, C., Sánchez, S. \& Soto, M. (2014). Creando un valor compartido a través de la responsabilidad social, empresarial y la sustentabilidad. On Ibarra L., Casas E., Olivas E., Jacobo C., Leyva B. Sustentabilidad, empresa y agroindustria: Reflexiones y aplicaciones. Ed. Umbral. Mexico. pp.237-253. Ed. Umbral digital.

17. Naciones Unidas (1987). Informe de la comisión mundial sobre el medio ambiente y el desarrollo (Informe Brundtland). Accessed February 23, 2015 on http://es.scribd.com/doc/105305734/ONU-InformeBrundtland-Ago-1987-Informe-de-la-Comision-Mundialsobre-Medio-Ambiente-y-Desarrollo\#scribd

18. Rubio V. (1999). La gestión ambiental en la pequeña y mediana empresa. Departamento de Industria y Medio Ambiente, Cámara de Comercio, Industria y Navegación de Castellón. Spain. Accessed february 25, 2015 on http://www.ces.gva.es/pdf/conferencias/02/3.pdf

19. SAGARPA (2011). Es Sonora el mayor exportador de productos agropecuarios y pesqueros del país. Accessed February 25, $2015 \quad$ on http://www.sagarpa.gob.mx/Delegaciones/sonora/boletines /Paginas/B0822011.aspx

20. SAGARPA (2012). Puntos a destacar del sector agroalimentario de México (evaluación al cierre del año 2012). Accessed January 26, 2015 on http://www.sagarpa.gob.mx/agronegocios/Documents/XA GRO2012.pdf

21. Tapia J. (2006). Apertura comercial y eficiencia económica del sector agropecuario de México en el TLCAN. Revista Comercio Exterior Vol. 56, num. 8, 2002, pp. 694-7902. Mexico. Accessed February 4, 2015 on http://revistas.bancomext.gob.mx/rce/magazines/94/4/Tapi a.pdf

22. Vargas-Hernández J. (2010). Sustentabilidad organizacional para el desarrollo ambiental y económico, el caso de micro empresas en San Sebastián del Sur. Revista Venezolana de Análisis de Coyuntura, vol. XVI, núm. 1, pp. 187-210, Universidad Central de Venezuela. Venezuela. Accessed January 25, 2015 on http://www.redalyc.org/articuloBasic.oa?id=36415689009 
23. Velázquez, R.M. \& Bojórquez, M.G. (2014). Indicadores de sustentabilidad en los servicios microfinancieros. En Ibarra, L.E., Casas, E.V., Olivas, E., Jacobo, C.A. y Leyva, B.A.
(Coord.). Sustentabilidad, empresa y agroindustria: reflexiones y aplicaciones. (pp. 111-113). Mexico. Ed. Umbral digital. 